\title{
Faktor-Faktor yang Berhubungan dengan Pemanfaatan Obat Tradisional pada Pasien Hiperkolesterolemia di Rumah Riset Jamu "Hortus Medicus"
}

\author{
Tyas F. Dewi, Ulfatun Nisa \\ Balai Besar Penelitian dan Pengembangan Tanaman Obat \\ dan Obat Tradisional, Karanganyar, Indonesia
}

\begin{abstract}
Abstrak
Beberapa tahun terakhir ini, terjadi pergeseran pola penyakit dari penyakit menular menjadi penyakit tidak menular, termasuk hiperkolesterolemia. Peningkatan tersebut didukung dengan meningkatnya jumlah kunjungan pasien khususnya pasien hiperkolesterolemia ke Rumah Riset Jamu (RRJ) Hortus Medicus sebagai fasilitas pelayanan kesehatan tradisional pada tahun 2016 sebesar 65\% dibandingkan dengan tahun sebelumnya. Tujuan penelitian ini adalah mengetahui faktor yang memengaruhi pemilihan pengobatan tradisional tersebut. Penelitian ini merupakan studi nonintervensi dengan desain penelitian potong lintang yang dilakukan terhadap 150 responden di RRJ Hortus Medicus pada bulan April-Oktober 2017. Pertanyaan pada kuesioner mengacu kepada teori Ronald Andersen. Responden dikelompokkan berdasarkan frekuensi kunjungan ke RRJ Hortus Medicus yaitu kategori jarang, terkadang, dan sering. Korelasi antara variabel bebas dan variabel terikat (perilaku pemilihan pengobatan) dianalisis menggunakan analisis Chi-Square. Hasil yang diperoleh menunjukkan bahwa usia $(\mathrm{p}=0,000)$, pekerjaan $(\mathrm{p}=0,008)$, waktu tempuh yang dibutuhkan dari rumah ke tempat pengobatan tradisional $(p=0,025)$, pengetahuan tentang pengobatan tradisional $(\mathrm{p}=0,004)$, tarif pengobatan tradisional $(\mathrm{p}=0,011)$, dan pandangan subjektif responden $(\mathrm{p}=0,008)$ memiliki hubungan yang signifikan secara statistik terhadap perilaku pemilihan pengobatan. Hal ini berarti faktor yang berhubungan pada pemilihan pengobatan tradisional adalah faktor predisposisi pasien (umur, pekerjaan, pengetahuan, waktu tempuh), faktor pendukung (tarif), dan faktor kebutuhan (pandangan subjektif).
\end{abstract}

Kata kunci: Hiperkolesterol, obat tradisional, pemanfaatan pengobatan

\section{Factors Related to Traditional Healthcare Utilization at Hypercholesterolemic Patient in Jamu Research Center "Hortus Medicus"}

\begin{abstract}
In recent years, there has been a shift in the pattern of diseases from infectious diseases to non-infectious diseases, including hypercholesterolemia. This shifted was supported by the increasing number of patient visits, especially hypercholesterolemic patients to Jamu Research Center (RRJ) Hortus Medicus as traditional health care facilities in 2016 at $65 \%$ compared to the previous year. The purpose of this study was to determine the factors that influence the choice of traditional medicine. This study is a non-intervention study with a cross-sectional design conducted on 150 respondents in the RRJ Hortus Medicus in AprilOctober 2017. The questions on the questionnaire refer to Ronald Andersen's theory. Respondents were grouped based on the frequency of visits to the RR Hortus Medicus, namely: categories rare, sometimes, and often. The correlation between the independent variables and the dependent variable (treatment selection behavior) was analyzed using Chi-Square analysis. The results obtained showed that age $(p=0.000)$, occupation $(p=0.008)$, travel time needed from home to place of traditional medicine $(p=0.025)$, knowledge of traditional medicine $(p=0.004)$, traditional medicine rates $(p=0.011)$, and the perceived opinion of the respondents $(\mathrm{p}=0.008)$ has a statistically significant relationship to the behavior of choosing treatment. This means that factors related to the selection of traditional medicine are predisposing factors for patients (age, occupation, knowledge, travel time), supporting factors (rates), and factors of need (perceived opinion).
\end{abstract}

Keywords: Healthcare, herbal medicine, hypercholesterolemia

Korespondensi: Tyas F. Dewi, S.Farm., Apt., Balai Besar Penelitian dan Pengembangan Tanaman Obat dan Obat Tradisional, Karanganyar, Jawa Tengah 57792, Indonesia, email: tyasfriskadewi@gmail.com

Naskah diterima: 14 Februari 2018, Diterima untuk diterbitkan: 15 Februari 2019 , Diterbitkan: 1 Maret 2019 


\section{Pendahuluan}

Saat ini, terjadi suatu perubahan pola kejadian penyakit atau yang disebut dengan transisi epidemiologi. Transisi epidemiologi ditandai oleh perubahan pola penyakit dan kematian yang pada awalnya didominasi oleh penyakit infeksi, lalu mengalami peralihan ke penyakit noninfeksi atau penyakit tidak menular. ${ }^{1}$ Menurut Handajani et al. (2009), penyakit degeneratif menjadi penyebab kematian terbesar di dunia hingga saat ini, dan sekitar 17 juta orang meninggal lebih awal setiap tahun akibat epidemi global penyakit degeneratif. ${ }^{2}$ Perubahan pola penyakit ini dipengaruhi oleh keadaan demografi (pendidikan, umur, dan jenis kelamin), sosial ekonomi (pendapatan) dan sosial budaya. ${ }^{3}$

Hiperkolesterolemia, didefinisikan sebagai kadar kolesterol dalam darah setidaknya yaitu $240 \mathrm{mg} / \mathrm{dL}$, termasuk ke dalam penyakit yang tidak menular. ${ }^{4}$ Abnormalitas kadar lipid dalam darah adalah salah satu faktor risiko munculnya penyakit-penyakit kardiovaskular danmetabolik, seperti aterosklerosis, penyakit jantung koroner, stroke, sindrom metabolik dan lain-lain. Prevalensi hiperkolesterolemia di Indonesia cukup tinggi. Menurut data Riset Kesehatan Dasar (Riskesdas) tahun 2013, pada penduduk yang berusia $>15$ tahun, sebanyak $35,9 \%$ di antaranya mempunyai kolesterol total abnormal dengan jumlah dari penduduk perempuan lebih banyak dibandingkan lakilaki, dan penduduk perkotaan lebih banyak dibandingkan pedesaan. ${ }^{5}$

Pengobatan hiperkolesterolemia dapat dilakukan secara medis menggunakan obatobatan konvensial, atau dengan pengobatan tradisional dengan tanaman obat. Tanaman obat yang secara saintifik telah terbukti memiliki khasiat sebagai antihiperkolesterolemia yaitu ramuan daun jati cina, daun jati belanda, herba tempuyung, herba teh hijau, rimpang temulawak, rimpang kunyit, dan herba meniran. ${ }^{6}$

Adanya peningkatan jumlah pasien, terutama pasien hiperkolesterolemia di Rumah Riset Jamu (RRJ) Hortus Medicus, menunjukkan ketertarikan masyarakat untuk menggunakan pelayanan kesehatan tradisional dari tahun ke tahun terus meningkat. Hal ini sejalan dengan tujuan pengaturan saintifikasi jamu yakni agar pemerintah dapat menyediakan jamu yang aman dikonsumsi, mempunyai khasiat nyata yang telah teruji secara ilmiah, dan dapat dimanfaatkan secara luas oleh masyarakat. Namun, hal ini seyogianya diikuti dengan peningkatan kualitas dari pelayanan kesehatan yang diberikan.

Untuk dapat meningkatkan kualitas dari pelayanan kesehatan, penting untuk mengetahui alasan masyarakat memanfaatkan pelayanan kesehatan, salah satunya adalah terpenuhinya kebutuhan dan tuntutan masyarakat yang merupakan gambaran dari masalah kesehatan masyarakat tersebut. Penelitian tentang faktorfaktor yang berhubungan dengan penggunaan obat tardisional di RRJ Hortus Medicus telah dilakukan untuk penyakit hipertensi, radang sendi, dan diabetes melitus, ${ }^{7}$ sedangkan untuk penyakit hiperkolesterolemia belum pernah dilakukan sebelumnya. Oleh karena itu, penelitian ini dilakukan dengan tujuan untuk mengetahui faktor-faktor yang berhubungan dengan tindakan/perilaku pencarian pengobatan tradisional pasien hiperkolesterolemia yang berkunjung ke RRJ Hortus Medicus.

\section{Metode}

Penelitian ini dilaksanakan di Rumah Riset Jamu (RRJ) Hortus Medicus Balai Besar Penelitian dan Pengembangan Tanaman Obat dan Obat Tradisional (B2P2TOOT) Tawangmangu Badan Penelitian dan Pengembangan Kesehatan Kementerian Kesehatan Republik Indonesia pada bulan Maret sampai dengan Oktober tahun 2017. Penelitian ini berjenis nonintervensi dengan desain penelitian potong lintang. Sampel pada penelitian ini adalah responden yang terdiagnosis oleh dokter di RRJ Hortus 
Medicus menderita hiperkolesterolemia, dan telah menandatangani informed consent. Jumlah sampel pada penelitian ini yaitu 150 pasien yang didapatkan dengan rumus perhitungan pasien simple random sampling, didasarkan pada jumlah dari populasi hiperkolesterolemia tahun 2016 di RRJ Hortus Medicus yakni 1235 orang. Penelitian ini telah mendapatkan persetujuan Komisi Etik Badan Litbangkes dengan nomor LB.02.01/2/KE.104/2017. Instrumen pada penelitian ini adalah kuesioner yang telah diuji validitas dan reliabilitasnya.

Pertanyaan yang terdapat pada kuesioner didasarkan pada teori Ronald A. Andersen mengenai perilaku pencarian pengobatan. ${ }^{8}$ Beberapa faktor yang diduga berhubungan dengan perilaku dari seseorang ialah faktor predisposisi, faktor pendukung, dan faktor kebutuhan.

Faktor predisposisi pada penelitian ini terdiri dari demografi (usia, jenis kelamin, status pernikahan pasien), tingkat pendidikan, pekerjaan, waktu tempuh yang dibutuhkan dari rumah menuju RRJ Hortus Medicus terlepas dari alat transportasi yang digunakan pasien, nilai tentang kesehatan dan penyakit (persepsi mobiditas), pengetahuan terhadap pengobatan tradisional, dan sikap terhadap pengobatan tradisional. Usia responden dibagi ke dalam 6 kategori, yaitu $<30$ tahun, 30-39 tahun, 40-49 tahun, 50-59 tahun, dan $>60$ tahun. Status pernikahan dibedakan menjadi belum menikah, sudah menikah, dan duda/ janda.

Tingkat pendidikan dikategorikan menjadi responden dengan tingkat pendidikan tinggi adalah responden yang lulus SMA atau lebih tinggi, sedangkan responden yang memiliki tingkat pendidikan rendah adalah responden yang berpendidikan SMP atau lebih rendah. Pekerjaan responden dibagi menjadi responden yang tidak bekerja, bekerja sebagai PNS/TNI/ POLRI, pekerja swasta, wiraswasta, serta buruh. Waktu tempuh dari rumah responden menuju tempat pengobatan dikelompokkan menjadi dekat ( $\leq 1$ jam), sedang (1-2 jam), dan jauh ( $\geq 3$ jam). Nilai tentang sehat dan sakit diperoleh dengan mengajukan beberapa pertanyaan tentang keadaan sehat dan sakit, serta respon yang dilakukan apabila sakit. Jawaban dari masing-masing poin diberikan skoring, kemudian dikelompokkan ke dalam kategori baik, sedang, dan cukup. Cara yang sama juga dilakukan untuk mengelompokkan tingkat pengetahuan responden dan sikap terhadap pengobatan tradisional. Pertanyaan untuk variabel pengetahuan meliputi jenis pelayanan kesehatan yang disebutkan apakah termasuk ke dalam pengobatan tradisional, pengobatan modern, atau responden tidak tahu, apakah RRJ Hortus Medicus termasuk dalam pengobatan tradisional atau bukan, dari manakah responden mendapatkan informasi tentang RRJ Hortus Medicus, pendapat dari reseponden mengenai apakah yang dimaksud dengan pengobatan tradisional, bahan apa sajakah yang diperbolehkan ada dalam obat tradisional, serta penyakit apa sajakah yang dapat diobati dengan pengobatan tradisional. Pengetahuan responden dikelompokkan menjadi pengetahuan tinggi dan rendah. Pertanyaan untuk sikap terhadap pengobatan tradisional meliputi pendapat tentang pengobatan yang lebih efektif untuk hiperkolesterol, alasan dalam menggunakan obat tradisional, serta keyakinan terhadap khasiat dan keamanan obat tradisional. Sikap terhadap pengobatan tradisional dikelompokkan menjadi baik, sedang, dan kurang.

Faktor pendukung terdiri dari kemampuan daya beli jasa pelayanan dan keikutsertaan dalam jaminan kesehatan. Tarif pengobatan yang ditetapkan untuk seluruh pasien di RRJ Hortus Medicus adalah sama, yaitu Rp20.000,00 untuk pengobatan satu minggu. Tarif tersebut menurut pendapat responden dikategorikan menjadi murah, sedang, dan mahal. Kesesuaian tarif yang ditetapkan dibedakan menjadi sangat sesuai, sesuai, dan kurang sesuai.

Faktor kebutuhan terdiri dari pandangan 
subjektif terhadap penyakit dibedakan menjadi pandangan subjektif yang baik dan pandangan subjektif yang buruk. Faktor-faktor tersebut merupakan variabel bebas dalam penelitian ini, sedangkan variabel terikatnya adalah pemilihan pengobatan tradisional. Frekuensi penggunaan pengobatan tradisional, dihitung mulai dari kunjungan pertama pasien ke RRJ Horus Medicus, ditetapkan menjadi kategori jarang (baru mencoba atau kunjungan awal pengobatan tradisional pasien), terkadang (responden yang sudah pernah berkunjung 2-4 kali kunjungan), dan sering (responden yang telah berkunjung lebih dari 5 kali atau menggunakan pengobatan tradisional sebagai layanan kesehatan rujukan saat mengalami gangguan kesehatan).

Data kemudian dihitung menggunakan analisis univariat untuk menjelaskan dan mendiskripsikan variabel penelitian serta melihat distribusinya, baik varibel bebas maupun variabel terikat. Untuk mengetahui hubungan dua variabel yang diteliti dilakukan analisis bivariat uji Chi-Square, dengan nilai confident interval sebesar 95\% dan Fisher exact. Analisis data dilakukan dengan software SPSS versi 22.

\section{Hasil}

Jumlah responden terbanyak berusia lebih dari 60 tahun, sebagian besar responden adalah berjenis kelamin laki-laki, dan status dari pernikahan responden didominasi oleh responden yang sudah menikah. Karakteristik responden dan jawaban dari kuesioner yang lebih lengkap dapat dilihat pada Tabel 1 . Usia, pekerjaan, jarak rumah dengan tempat pengobatan tradisional, dan pengetahuan mengenai pengobatan tradisional merupakan faktor predisposisi responden yang secara statistik memiliki korelasi dengan pemilihan pengobatan tradisional pada penelitian ini. Hasil uji statistik yang lebih lengkap dapat dilihat pada Tabel 2.

\section{Pembahasan}

Upaya pencarian pengobatan dapat diartikan sebagai suatu sikap/tindakan yang dilakukan seseorang dalam kondisi sakit untuk mencari atau memilih pengobatan profesional atau tidak. ${ }^{9}$ Perilaku pemanfaatan pengobatan di masyarakat sangat bervariasi berdasarkan pada jumlah dan jenis sarana pelayanan kesehatan yang tersedia. Masyarakat memiliki pilihan yang lebih beragam dalam melakukan pencarian pengobatan jika di wilayah tersebut banyak tersedia sarana pelayanan kesehatan termasuk tempat pengobatan tradisional.

Peningkatan jumlah responden sebanding dengan peningkatan usia responden, sesuai dengan pernyataan Reiner et al. (2017), bahwa laki-laki usia $\geq 40$ tahun atau wanita dengan usia $\geq 50$ tahun memiliki risiko yang tinggi terhadap timbulnya hiperkolesterolemia. ${ }^{10}$ Penggunaan obat tradisional pada kelompok usia $>56$ tahun di Indonesia kemungkinannya 1,66 kali lebih tinggi dibandingkan dengan responden yang berusia $<56$ tahun. Kelompok usia $>56$ tahun lebih menyukai penggunaan obat tradisional sebab penggunaannya lebih mudah dan praktis. ${ }^{11}$ Namun, hasil penelitian ini tidak sesuai dengan penelitian Radji et al. (2010) yang menyebutkan bahwa tidak ada hubungan bermakna antara penggunaan obat herbal dengan usia pasien. ${ }^{12}$

Pekerjaan responden memiliki hubungan yang bermakna $(p=0,08)$ dengan pemilihan pengobatan. Hasil penelitian ini berbeda dengan penelitian Tampi et al. (2016) yang menyatakan bahwa tidak adanya hubungan antara pekerjaan dengan pemanfaatan dari pelayanan kesehatan di RSUD Manembo Nembo Bitung. ${ }^{13}$ Penelitian lain mengenai penggunaan obat herbal pada pasien kanker serviks juga menunjukkan bahwa pekerjaan pasien tidak memiliki pengaruh terhadap alasan penggunaan obat herbal. ${ }^{12}$ Apabila dikaitkan dengan hasil survey di RRJ Hortus Medicus, yang pendaftaran pasien dilakukan pada hari 
Tabel 1 Karakteristik Jawaban Responden

\begin{tabular}{|c|c|c|c|c|}
\hline \multirow[b]{2}{*}{ Variabel } & \multicolumn{3}{|c|}{ Pemilihan Pengobatan Tradisional } & \multirow{2}{*}{$\begin{array}{l}\text { Total } \\
(\mathrm{n}, \%)\end{array}$} \\
\hline & $\begin{array}{c}\text { Jarang } \\
(n, \%) \\
\end{array}$ & $\begin{array}{c}\text { Terkadang } \\
(\mathbf{n}, \%)\end{array}$ & $\begin{array}{l}\text { Sering } \\
(\mathrm{n}, \%) \\
\end{array}$ & \\
\hline $\begin{array}{l}\text { Usia } \\
<30 \text { tahun } \\
30-39 \text { tahun } \\
40-49 \text { tahun } \\
50-59 \text { tahun } \\
>60 \text { tahun }\end{array}$ & $\begin{array}{c}0(0,00) \\
2(10,53) \\
12(33,33) \\
4(10,53) \\
4(9,52)\end{array}$ & $\begin{array}{r}12(80,00) \\
8(42,11) \\
10(27,78) \\
8(21,05) \\
12(28,57)\end{array}$ & $\begin{array}{r}3(20,00) \\
9(47,37) \\
14(38,89) \\
26(68,42) \\
26(61,90)\end{array}$ & $\begin{array}{l}15(100,00) \\
19(100,00) \\
36(100,00) \\
38(100,00) \\
42(100,00)\end{array}$ \\
\hline $\begin{array}{l}\text { Jenis Kelamin } \\
\text { Laki-laki } \\
\text { Perempuan }\end{array}$ & $\begin{array}{r}16(17,39) \\
6(10,34)\end{array}$ & $\begin{array}{l}30(32,61) \\
20(34,48)\end{array}$ & $\begin{array}{l}46(50,00) \\
32(55,17)\end{array}$ & $\begin{array}{l}92(100,00) \\
58(100,00)\end{array}$ \\
\hline $\begin{array}{l}\text { Status Pernikahan } \\
\text { Belum menikah } \\
\text { Sudah menikah } \\
\text { Duda/Janda }\end{array}$ & $\begin{array}{c}0(0,00) \\
21(15,91) \\
1(9,09)\end{array}$ & $\begin{array}{r}5(71,43) \\
40(30,30) \\
5(45,45)\end{array}$ & $\begin{array}{c}2(28,57) \\
71(53,79) \\
5(45,45)\end{array}$ & $\begin{array}{r}7(100,00) \\
132(100,00) \\
11(100,00)\end{array}$ \\
\hline $\begin{array}{l}\text { Tingkat Pendidikan } \\
\text { Rendah } \\
\text { Tinggi }\end{array}$ & $\begin{array}{r}7(14,29) \\
15(14,85)\end{array}$ & $\begin{array}{l}15(30,61) \\
35(34,65)\end{array}$ & $\begin{array}{l}27(55,10) \\
51(50,50)\end{array}$ & $\begin{array}{r}49(100,00) \\
101(100,00)\end{array}$ \\
\hline $\begin{array}{l}\text { Pekerjaan } \\
\text { Tidak bekerja } \\
\text { PNS/TNI/POLRI } \\
\text { Pekerja swasta } \\
\text { Wiraswasta } \\
\text { Buruh }\end{array}$ & $\begin{array}{l}9(16,98) \\
1(5,00) \\
1(3,45) \\
8(20,00) \\
3(37,50)\end{array}$ & $\begin{array}{r}10(18,87) \\
9(45,00) \\
17(58,62) \\
12(30,00) \\
2(25,00)\end{array}$ & $\begin{array}{r}34(64,15) \\
10(50,00) \\
11(37,93) \\
20(50,00) \\
3(37,50)\end{array}$ & $\begin{array}{r}53(100,00) \\
20(100,00) \\
29(100,00) \\
40(100,00) \\
8(100,00)\end{array}$ \\
\hline $\begin{array}{l}\text { Waktu Tempuh } \\
\text { Pendek } \\
\text { Sedang } \\
\text { Panjang }\end{array}$ & $\begin{array}{c}1(3,85) \\
7(9,46) \\
14(28,00)\end{array}$ & $\begin{array}{r}9(34,62) \\
27(36,49) \\
14(28,00)\end{array}$ & $\begin{array}{l}16(61,54) \\
40(54,05) \\
22(44,00)\end{array}$ & $\begin{array}{l}26(100,00) \\
74(100,00) \\
50(100,00)\end{array}$ \\
\hline $\begin{array}{l}\text { Sikap terhadap Pengobat: } \\
\text { Baik } \\
\text { Cukup } \\
\text { Kurang }\end{array}$ & $\begin{array}{r}7(20,00) \\
11(11,00) \\
4(26,67)\end{array}$ & $\begin{array}{l}12(34,29) \\
32(32,00) \\
40(40,00)\end{array}$ & $\begin{array}{r}16(45,71) \\
57(57,00) \\
5(33,33)\end{array}$ & $\begin{array}{r}35(100,00) \\
100(100,00) \\
15(100,00)\end{array}$ \\
\hline $\begin{array}{l}\text { Pengetahuan } \\
\text { Rendah } \\
\text { Tinggi }\end{array}$ & $\begin{array}{c}15(22,06) \\
7(8,54)\end{array}$ & $\begin{array}{l}27(39,71) \\
23(28,05)\end{array}$ & $\begin{array}{l}26(38,24) \\
52(63,41)\end{array}$ & $\begin{array}{l}68(100,00) \\
82(100,00)\end{array}$ \\
\hline $\begin{array}{l}\text { Nilai tentang Sehat dan Sa } \\
\text { Baik } \\
\text { Sedang } \\
\text { Kurang }\end{array}$ & $\begin{array}{r}15(78,95) \\
19(16,52) \\
2(12,50)\end{array}$ & $\begin{array}{c}1(5,26) \\
38(33,04) \\
7(43,75)\end{array}$ & $\begin{array}{r}3(15,79) \\
58(50,43) \\
7(43,75)\end{array}$ & $\begin{array}{r}19(100,00) \\
115(100,00) \\
16(100,00)\end{array}$ \\
\hline $\begin{array}{l}\text { Tarif } \\
\text { Rendah } \\
\text { Sedang } \\
\text { Tinggi }\end{array}$ & $\begin{array}{c}10(9,17) \\
12(29,27) \\
0(0,00)\end{array}$ & $\begin{array}{c}40(36,70) \\
10(24,39) \\
0(0,00)\end{array}$ & $\begin{array}{c}59(54,13) \\
19(46,34) \\
0(0,00)\end{array}$ & $\begin{array}{r}109(100,00) \\
41(100,00) \\
0(0,00)\end{array}$ \\
\hline $\begin{array}{l}\text { Kesesuaian Tarif } \\
\text { Sangat Sesuai } \\
\text { Sesuai } \\
\text { Kurang Sesuai }\end{array}$ & $\begin{array}{c}11(18,97) \\
11(12,09) \\
0(0,00)\end{array}$ & $\begin{array}{c}21(36,21) \\
29(31,87) \\
0(0,00)\end{array}$ & $\begin{array}{l}26(44,83) \\
51(56,04) \\
1(100,00)\end{array}$ & $\begin{array}{r}58(100,00) \\
91(100,00) \\
1(100,00)\end{array}$ \\
\hline $\begin{array}{l}\text { Keikutsertaan Asuransi } \\
\text { Tidak ikut } \\
\text { Ikut }\end{array}$ & $\begin{array}{r}7(17,50) \\
15(13,64)\end{array}$ & $\begin{array}{l}14(35,00) \\
36(32,73)\end{array}$ & $\begin{array}{l}19(47,50) \\
59(53,64)\end{array}$ & $\begin{array}{r}40(100,00) \\
110(100,00)\end{array}$ \\
\hline $\begin{array}{l}\text { Pandangan Subjektif } \\
\text { Baik } \\
\text { Buruk }\end{array}$ & $\begin{array}{c}22(16,79) \\
0(0,00)\end{array}$ & $\begin{array}{l}39(29,77) \\
11(57,89)\end{array}$ & $\begin{array}{r}70(53,44) \\
8(42,11) \\
\end{array}$ & $\begin{array}{r}131(100,00) \\
19(100,00) \\
\end{array}$ \\
\hline
\end{tabular}


Tabel 2 Analisis Bivariat dari Variabel Penelitian

\begin{tabular}{llc}
\hline \multicolumn{1}{c}{ Faktor yang Berhubungan } & Variabel & Nilai p \\
\hline Faktor Predisposisi & Umur & 0,000 \\
& Jenis kelamin & 0,477 \\
& Status pernikahan & 0,185 \\
& Tingkat pendidikan & 0,859 \\
& Jenis pekerjaan & 0,008 \\
& Waktu tempuh & 0,025 \\
& Nilai tentang sehat dan sakit & 0,436 \\
& Pengetahuan pasien & 0,004 \\
Faktor Pendukung & Sikap terhadap pengobatan tradisional & 0,293 \\
& Tarif pengobatan & 0,011 \\
& Kesesuaian tarif & 0,479 \\
Karakteristik Kebutuhan & Keikutsertaan dalam jaminan kesehatan & 0,760 \\
\hline
\end{tabular}

Senin-Jumat pukul 07.30-11.30 WIB, pasien bekerja yang bekerja pada sektor formal harus mengambil cuti atau izin tidak masuk kerja untuk berobat di RRJ Hortus Medicus. Hal ini tentu menjadi sebuah penghalang bagi responden yang ingin melakukan pengobatan. Faktor pekerjaan pada penelitian ini tidak menunjukkan status ekonomi pasien.

Aksesibilitas responden memiliki hubungan dengan pemilihan pengobatan tradisional. Responden yang rumahnya membutuhkan waktu tempuh sedang (yakni selama 1-2 jam) lebih sering berobat ke RRJ Hortus Medicus jika dibandingkan pasien yang membutuhkan waktu tempuh lebih panjang. Jarak yang jauh terbukti menghambat pasien dalam memilih pengobatan. ${ }^{14}$ Namun, hal berbeda ditemukan pada responden yang membutuhkan waktu tempuh lebih pendek yang jumlahnya paling sedikit di antara responden dengan waktu tempuh sedang dan panjang. Hal ini dapat disebabkan oleh rendahnya prevalensi dari pasien penderita hiperkolesterolemia di daerah sekitar RRJ Hortus Medicus yaitu kecamatan Tawangmangu, yang merupakan kawasan pedesaan. Hasil Riskesdas pada tahun 2013 menunjukkan bahwa hiperkolesterolemia lebih banyak ditemui pada masyarakat perkotaan dibandingkan pedesaan. ${ }^{5}$

Sebagian besar responden (54,67\%) mempunyai tingkat pengetahuan yang tinggi mengenai pengobatan tradisional. Hasil uji statistik menunjukkan bahwa pengetahuan memiliki hubungan yang bermakna dengan perilaku pemilihan pengobatan. Pengetahuan merupakan salah satu faktor predisposisi yang dapat menentukan dan memengaruhi perilaku seseorang. Hasil penelitian yang dilakukan oleh Pratiwi et al. (2014) menyatakan terdapat pengaruh pengetahuan responden terhadap perilaku swamedikasi obat AINS walaupun sangat rendah. Hasil penelitian lain tentang determinan pemilihan pengobatan tradisional menggunakan media lintah menunjukkan bahwa terdapat hubungan yang signifikan antara pengetahuan dengan tindakan pengobatan. ${ }^{15}$

Faktor predisposisi yang lainnya, seperti jenis kelamin, status dari pernikahan, tingkat pendidikan responden, sikap responden terhadap pengobatan tradisional, serta nilai mengenai sehat dan sakit pada hasil penelitian ini tidak memiliki hubungan yang bermakna dengan penggunaan obat tradisional. Sebagian besar dari responden penelitian memiliki tingkat pendidikan yang tinggi yakni 67,33\%. Faktor pendidikan tidak memiliki hubungan bermakna 
dengan pemilihan pengobatan. Hasil penelitian ini sejalan dengan penelitian yang dilakukan oleh Rahman et al. (2016) yang menyatakan bahwa tingkat pendidikan responden tidak berhubungan dengan pemilihan pengobatan. ${ }^{16}$ Hasil penelitian yang dilakukan oleh Jennifer et al. (2015) menyatakan hal yang sama, bahwa pendidikan tidak memiliki hubungan terhadap probabilitas individu untuk memilih pengobatan tradisiona $1^{17}$

Dalam penelitian ini, nilai sehat dan sakit (persepsi morbiditas) juga tidak berhubungan secara statistik dengan pemilihan pengobatan. Persepsi sehat-sakit oleh pasien merupakan representasi kognitif maupun respon emosi yang dirasakan oleh pasien terhadap kondisi kesehatannya. Persepsi ini mempunyai faktor penyusun, baik berupa kesadaran terhadap konsekuensi penyakitnya, kesadaran akan waktu perawatan, identifikasi dari penyakit yang dideritanya maupun respon emosi terhadap penyakit. ${ }^{18}$ Nilai sehat dan sakit dari responden pada penelitian ini sebagian besar termasuk dalam kategori sedang. Hal ini sejalan dengan penelitian Rahman et al. (2016) yang menyebutkan bahwa persepsi sakit berhubungan dengan perilaku pencarian pelayanan kesehatan pada santri di Pondok Pesantren Al Bisyri Tinjomoyo Semarang, ${ }^{16}$ sedangkan pada penelitian Safitri et al. (2016) dinyatakan bahwa nilai sehat sakit responden berhubungan bermakna terhadap pemilihan pengobatan. ${ }^{15}$

Faktor pendukung yang memiliki hubungan secara bermakna terhadap perilaku pemilihan pengobatan tradisional adalah kemampuan dalam membeli jasa pelayanan, sedangkan keikutsertaan dalam jaminan kesehatan tidak bermakna secara statistik. Sebagian besar responden menilai bahwa tarif yang dikenakan RRJ Hortus Medicus termasuk rendah, dan dengan tarif tersebut, 91 responden menilai tarif tersebut sesuai, bahkan sebanyak 58 responden menilai tarif tersebut sangat sesuai dengan pengobatan yang didapatkan. Hanya 1 responden yang menilai tarif yang dikenakan tersebut tidak sesuai. Hal ini berarti responden merasa puas dengan pelayanan pengobatan tradisional yang diberikan oleh RRJ Hortus Medicus. Hasil penelitian Kamaludin (2010) menyebutkan bahwa aspek ekonomi, yaitu harga terapi yang terjangkau, menjadi salah satu bahan pertimbangan dan alasan pasien memilih terapi tradisional tersebut. ${ }^{19}$

Faktor keikutsertaan pasien dalam jaminan kesehatan, pada penelitian ini tidak memiliki hubungan dengan pemilihan pengobatan. Pembiayaankesehatan di RRJHortus Medicus tidak ditanggung oleh BPJS. Hasil penelitian ini sesuai dengan penelitian yang dilakukan oleh Jennifer et al. (2016) yang menyatakan bahwa kepemilikan asuransi kesehatan tidak memiliki pengaruh terhadap probabilitas untuk memilih pengobatan tradisional. ${ }^{17}$ Hasil ini berbeda dengan penelitian yang dilakukan oleh Supadmi (2013) bahwa terdapat hubungan yang signifikan antara kepemilikan asuransi dengan perilaku pengobatan. ${ }^{20}$

Faktor kebutuhan pada penelitian ini adalah pandangan subjektif responden terhadap penyakit yang diderita yaitu hiperkolesterol. Menurut Setyoningsih et al. (2016), ada dua faktor utama yang menentukan perilaku sakit, yakni persepsi atau definisi individu tentang suatu situasi atau penyakit, serta kemampuan individu untuk melawan serangan penyakit tersebut dengan sebuah tindakan. Apabila pandangan subjektifnya baik, maka pasien dengan kesadaran sendiri mencari pengobatan untuk sakit yang diderita. Hampir seluruh responden pada penelitian ini mempunyai pandangan subjektif yang berada pada kategori baik. Pandangan subjektif memiliki hubungan secara statistik dengan perilaku pemilihan pengobatan. $^{21}$

Penelitian ini mempunyai keterbatasan yaitu pada penggunaan instrumen penelitian yang berupa kuesioner dengan pertanyaan bersifat tertutup (tersedia alternatif jawaban). Meski validitas dan reabilitas dari instrumen 
penelitian ini telah diusahakan, namun bias informasi dapat terjadi karena keterbatasan responden di dalam berpendapat. Responden tinggal menentukan pilihan jawaban yang tersedia sehingga terdapat faktor subjektifitas dan kejujuran yang sulit untuk dikendalikan sehingga dapat memengaruhi informasi yang diperoleh.

\section{Simpulan}

Faktor yang berhubungan pada pemilihan pengobatan tradisional yaitu faktor predisposisi (usia, pekerjaan, waktu tempuh yang dibutuhkan responden dari rumah ke tempat pengobatan, dan pengetahuan responden), faktor pendukung (tarif pengobatan tradisional), serta faktor kebutuhan (pandangan subjektif responden terhadap kondisi kesehatan).

\section{Ucapan Terima Kasih}

Terima kasih kepada Drs. Slamet Wahyono, M.Sc. Apt. dan Dr. Ir. Yuli Widiastuti, MP, selaku pembimbing lapangan atas komentar perbaikan dan saran penulisan yang telah diberikan.

\section{Pendanaan}

Penelitian ini dibiayai oleh Riset Pembinaan Kesehatan, Kementerian Kesehatan Republik Indonesia.

\section{Konflik Kepentingan}

Seluruh penulis menyatakan tidak terdapat potensi konflik kepentingan dengan penelitian, kepenulisan (authorship), dan atau publikasi artikel ini.

\section{Daftar Pustaka}

1. Djaja S. Transisi epidemiologi di Indonesia dalam dua dekade terakhir dan implikasi pemeliharaan kesehatan menurut survei kesehatan rumah tanggal, surkesnas, riskesdas (1986-2007). Bul Penelit Kesehat. 2012;40(3):142-53.

2. Handajani A, Roosihermiatie B, Maryani H. Faktor-faktor yang berhubungan dengan pola kematian pada penyakit degeneratif di Indonesia. Bul Penelit Sist Kesehat. 2010;13:42-53.

3. Rahajeng E, Tuminah S. Prevalensi hipertensi dan determinannya di Indonesia. Maj Kedokt Indon. 2009;59(12):580-7.

4. Lee DC, Sui X, Church TS, Lavie CJ, Jackson AS, Blair SN. Changes in fitness and fatness on the development of cardiovascular disease risk factors: Hypertension, metabolic syndrome, and hypercholesterolemia. J Am Coll Cardiol 2012;59(7):665-72. doi: 10.1016/j.jacc.2 011.11.013

5. Badan Penelitian dan Pengembangan Kesehatan Kementerian Kesehatan Republik Indonesia. Riset kesehatan dasar 2013. Jakarta: Kementerian Kesehatan Republik Indonesia; 2013.

6. Triyono A, Astana PW. Laporan penelitian uji klinis multi center ramuan formula jamu hipertensi, hiperglikemia, hiperurisemia, hiperkolesterolemia dibanding obat standar. J Farm Galen. 2017;4:13-9.

7. Ahmad FA. Analisis penggunaan jamu untuk pengobatan pada pasien di klinik saintifikasi jamu hortus medicus Tawangmangu tahun 2012 (tesis). Depok: Universitas Indoensia; 2012.

8. Aday LA, Andersen R. A framework for the study of access to medical care. Heal Serv Res. 1974;9(3):208-20.

9. Maiman LA, Becker MH. The health belief model: Origins and correlates in psychological theory. Health Educ Monogr. 2016;2(4):336-53. doi: 10.1177/ 1090198 17400200404

10. Reiner Z, Catapano AL, Backer G De, Graham I, Taskinen MR, Wiklund O, et al. 
ESC / EAS guidelines for the management of dyslipidaemias The Task Force for the management of dyslipidaemias of the European Society of Cardiology (ESC) and the European. Eur Heart J. 2017;32 (14):1769-818. doi: 10.1093/eurheartj/eh r158.

11. Supardi S, Susyanty AL. Penggunaan obat tradisional dalam upaya pengobatan sendiri di Indonesia (Analisis data susenas tahun 2007). Bul Penelit Kesehat. 2010;38 (2):80-9.

12. Radji M, Aldrat H, Harahap Y, Irawan C. Penggunaan obat herbal pada pasien kanker serviks. J Ilmu Kefarmasian Indones. 2010;8(1):33-9.

13. Tampi J, Rumayar AA, Tucunan AAT. Hubungan antara pendidikan, pendapatan dan pekerjaan dengan pemanfaatan pelayanan kesehatan di rumah sakit umum daerah Manembo-Nembo Bitung 2015. Kesmas. 2016;5(1):12-7.

14. Cotesea JPS, Nyorong M, Ibnu IF. Perilaku pencarian pengobatan masyarakat terhadap penyakit malaria di kelurahan Remu Utara, Distrik Sorong, Kota Sorong Papua Barat. Repos Univ Hasanudin. 2017;2(1):15562.

15. Safitri EM, Luthviatin N, Ririanty M. Determinan perilaku pasien dalam pengobatan tradisional dengan media lintah (Studi pada pasien terapi lintah di Desa Rengel Kecamatan Rengel Kabupaten
Tuban). J Pustaka Kesehat. 2016;4(1):181-7. 16. Rahman AN, Prabamurti PN, Riyanti E. Faktor-faktor yang berhubungan dengan perilaku pencarian pelayanan kesehatan (health seeking behavior) pada santri di Pondok Pesantren Al Bisyri Tinjomoyo Semarang. J Kesehat Masy. 2016;4(5): 246-58.

17. Jennifer H, Saptutyningsih E. Preferensi individu terhadap pengobatan tradisional di Indonesia. J Ekon Stud Pembang. 2015; 16(1):26-41. doi: 10.18196/jesp.2015.00 39.26-41

18. Nofiyanto E, Andarini S, Koeswo M. Perilaku komunikasi petugas berhubungan dengan persepsi sehat-sakit pasien rawat inap. J Kedokt Brawijaya 2015;28(4):355. doi: 10.21776/ub.jkb.2015.028.04.17

19. Kamaluddin R. Pertimbangan dan alasan pasien hipertensi menjalani terapi alternatif komplementer bekam di Kabupaten Banyumas. J Keperawatan Soedirman. 2010;5(2):95-104. doi: 10.20 884/1.jks.2010.5.2.276

20. Supadmi W. Gambaran pasien geriatri melakukan swamedikasi di Kabupaten Sleman. Pharmaciana. 2013;3(2):45-50. doi: 10.12928/pharmaciana.v3i2.430

21. Setyoningsih A, Artaria MD. Pemilihan penyembuhan penyakit melalui pengobatan tradisional non medis atau medis. Masy Kebud Polit. 2016;29(1):44-56. doi: 10.20 473/mkp.V29I12016.44-56 